\title{
Webinar dan Workshop Kesehatan Periodontal secara Digital di Era Pandemi COVID-19 di Sidoarjo
}

\section{Eka Fitri Augustina*1, Ernie Maduratna Setyawati², Achmad Zam Zam Aghasy3}

\author{
1,2Departemen Periodonsia, Fakultas Kedokteran Gigi, Universitas Airlangga, Indonesia \\ ${ }^{3}$ Indonesian Health Collaboration and Innovation Institute (IHCI Institute), Indonesia \\ *e-mail: $\underline{\text { eka-f-a@fkg.unair.ac.id }}^{1}$,ernie-m-s@fkg.unair.ac.id ${ }^{2}{ }_{2}$ aghasy @ihci-institute.net $^{3}$
}

\begin{abstract}
Abstrak
Penyakit periodontal merupakan penyakit dengan prevalensi 67,8\%, tertinggi setelah karies gigi. Penyakit periodontal yang dibiarkan akan meningkatkan resiko penyakit sistemik seperti diabetes mellitus, penyakit jantung, dan rheumatoid arthritis. Peran dokter gigi sangat penting terkait penyakit periodontal, terutama di masa pandemi COVID-19. Motode yang digunakan dalam kegiatan adalah webinar individual kepada kader kesehatan diikuti oleh 30 peserta kemudian diberikan video promosi kesehatan periodontal dan dijadwalkan secara individual untuk menjadi peserta dalam webinar individual bersama interviewer dokter gigi menggunakan Video Call Whatsapp. Sedangkan untuk webinar interaktif kepada dokter gigi di wilayah Sidoarjo diikuti oleh 30 peserta, kemudian diberikan video promosi kesehatan dentolaser secara interaktif. Indikator yang digunakan dalam tercapainya kegiatan ini menggunakan google form dengan mengisi pertanyaan pre-test dan post-test. Hasil kegiatan menunjukkan bahwa pre-test webinar individual kepada kader sebesar 5,367 dan post-test sebesar 8,633. Sedangkan untuk webinar interaksi dengan Dokter Gigi hasil pre-test sebesar 6,225 dan post-test sebesar 8,225. Kesimpulan dari kegiatan adalah webinar dapat meningkatkan pengetahuan masyarakat umum tentang pentingnya menjaga kesehatan gigi dan mulut terutama jaringan periodontal.
\end{abstract}

Kata kunci: Dentolaser, Pemberdayaan Masyarakat, Penyakit Periodontal, Preventif

\begin{abstract}
Periodontal disease is a disease with a prevalence of 67.8\%, the highest after dental caries. Periodontal disease that is left untreated will increase the risk of systemic diseases such as diabetes mellitus, heart disease, and rheumatoid arthritis. The role of dentists is very important regarding periodontal disease, especially during the COVID-19 pandemic. The method used in the activity is an individual webinar to health cadres followed by 30 participants then given a periodontal health promotion video and scheduled individually to participate in an individual webinar with a dentist interviewer using Video Call Whatsapp. As for the interactive webinar to dentists in the Sidoarjo area, 30 participants participated, then an interactive dentolaser health promotion video was given. The indicators used in achieving this activity use a google form by filling out pre-test and post-test questions. The results of the activity showed that the pre-test of the individual webinar to the cadres was 5.367 and the post-test was 8.633. As for the interaction webinar with Dentists, the results of the pre-test were 6.225 and the post-test was 8.225. The activity concludes that the webinar can increase the general public's knowledge about the importance of maintaining oral and dental health, especially periodontal tissue.
\end{abstract}

Keywords: Community Empowerment, Dentolaser, Periodontal disease, Preventive

\section{PENDAHULUAN}

Penyakit periodontal merupakan penyakit rongga mulut dengan prevalensi tertinggi kedua setelah karies gigi. Berdasarkan Riskesdas tahun 2018, prevalensi penyakit periodontal di Indonesia mencapai 67,8\% (Kemenkes RI, 2018). Penyakit periodontal yang tidak dirawat dapat meningkatkan risiko penyakit sistemik seperti penyakit diabetes mellitus, penyakit jantung dan pembuluh darah, dan rheumatoid athritis (Hegde \& Awan, 2019).

Puskesmas menjadi ujung tombak pelayanan kesehatan masyarakat. Dari puskesmas diharapkan keluarga-keluarga dapat diberdayakan agar setiap keluarga dapat menjadi sejahtera, maju, dan mandiri. Agar pemberdayaan keluarga dapat lebih menjangkau keluarga secara langsung, dibentuk kelompok-kelompok PKK dari tingkat RW, RT sampai tingkat dasa wisma. Selanjutnya peran dokter gigi puskesmas dan kader PKK yang mana anggotanya berasal dari ibu- 
ibu rumah tangga dalam meningkatkan taraf hidup dan derajat kesehatan di setiap keluarga sangat dibutuhkan. Upaya inilah yang diharapkan dapat mengurangi resiko penyakit periodontal yang disebabkan oleh bakteri plak gigi dan resistensi host, melalui webinar kepada kader PKK dan dokter gigi di Sidoarjo. Kegiatan ini bertujuan untuk mengurangi risiko penyakit periodontal, menurunkan prevalensi penyakit periodontal serta menurunkan risiko penyakit sistemik.

\section{METODE}

Pengabdian masyarakat ini dilakukan dengan menyelenggarakan webinar individual kepada kader kesehatan dan webinar interaktif kepada dokter gigi di wilayah Sidoarjo. Webinar individual dilakukan kepada 30 orang kader kesehatan yang mendaftarkan diri dan mengisi pretest menggunakan formulir digital (google form). Setelah melakukan pendaftaran, peserta kemudian akan diberikan video promosi kesehatan periodontal dan dijadwalkan secara individual untuk menjadi peserta dalam webinar individual bersama interviewer dokter gigi menggunakan Video Call Whatsapp. Saat webinar berlangsung, interviewer akan bertanya seputar jaringan periodontal yang telah diinformasikan dalam video promosi kesehatan. Setelah sesi interview selesai, interviewer akan mengoreksi pengetahuan kader terkait kesehatan jaringan periodontal yang masih belum sesuai, dan menjawab pertanyaan yang dilontarkan oleh kader. Post-test kemudian diberikan di akhir sesi webinar individual menggunakan formulir digital (google form).

Webinar interaktif dilakukan kepada dokter gigi di wilayah puskesmas Sidoarjo. Webinar diikuti 30 dokter gigi yang mendaftarkan diri dan mengisi pre-test menggunakan formulir digital (google form). Setelah melakukan pendaftaran, peserta kemudian akan diberikan video promosi kesehatan dentolaser dan dijadwalkan secara untuk menjadi peserta dalam webinar interaktif. Saat webinar berlangsung, narasumber memberikan pengetahuan mengenai jaringan periodontal dan memeragakan penggunaan alat dentolaser. Post-test kemudian diberikan di akhir sesi webinar individual menggunakan formulir digital (google form).

\section{HASIL DAN PEMBAHASAN}

\subsection{Webinar Individual terhadap Kader}

Sebelum dilakukan penyuluhan terhadap kader puskesmas, dilakukan tes terhadap pengetahuan kader mengenai kesehatan jaringan periodontal. Hasil pre-test menunjukkan rerata 5,367. Setelah dilakukan penyuluhan dan dilakukan post-test tampak adanya peningkatan pengetahuan dengan rerata skor 8,633. Sehingga, terdapat peningkatan nilai pengetahuan kader terhadap kesehatan jaringan periodontal sebelum dan sesudah penyuluhan.

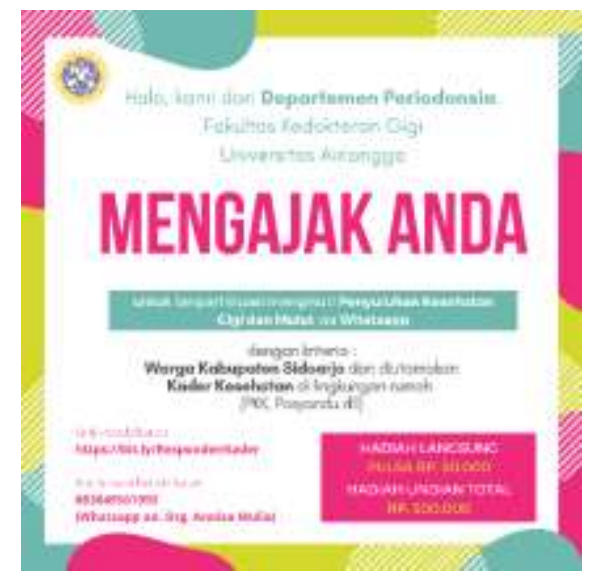

Gambar 1. Poster Webinar Individual terhadap Kader 


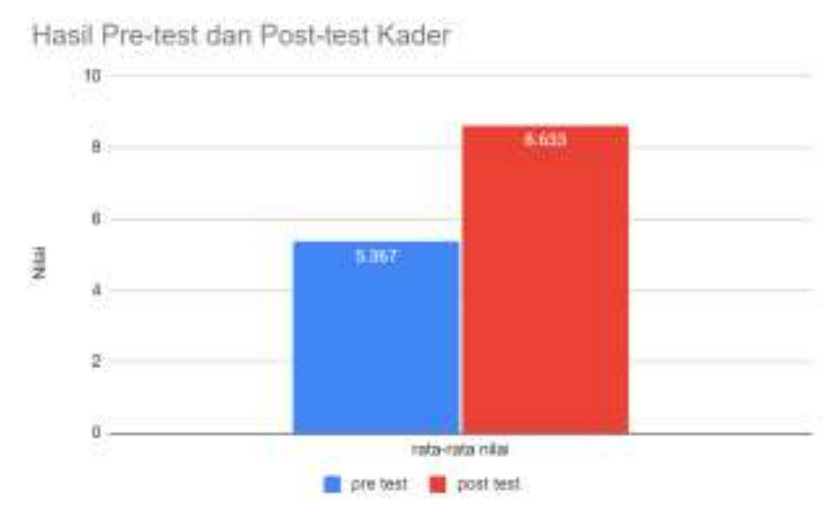

Gambar 2. Hasil Pre dan Post test Kader Puskesmas

Untuk memperdalam informasi yang telah diberikan melalui video, diadakan interview terhadap responden kader puskesmas. Dalam interview ini pemahaman 30 kader dites dengan menanyakan beberapa pertanyaan pokok yaitu pengertian penyakit periodontal, jenis penyakit periodontal, cara mencegah penyakit periodontal, cara menyikat gigi yang benar, serta manfaat dari periobrush. Sebelumnya responden ditanya mengenai video yang telah ditampilkan, sebagian besar responden merasa video tersebut mudah dipahami dan menarik tetapi ada beberapa responden yang merasa video terlalu cepat, sehingga ada beberapa informasi yang terlewat. Namun, setelah diberikan penjelasan lebih lanjut pada saat interview, responden menjadi lebih paham tentang materi yang disampaikan.

Ketika responden ditanya mengenai pengertian penyakit periodontal, sebagian besar menjawab penyakit periodontal merupakan penyakit pada jaringan penyangga gigi. Beberapa responden mampu menjelaskan hingga penyebab penyakit periodontal yang disebabkan plak atau karang gigi. Secara umum, seluruh responden sudah memiliki pengetahuan mengenai apa itu penyakit periodontal setelah menonton video yang diberikan. Contoh dari penyakit periodontal yang selalu disebut oleh responden adalah gingivitis, beberapa responden tidak menyebutkan periodontitis. Sebagian kecil mampu menjelaskan gingivitis yang tidak dirawat dapat berlanjut menjadi periodontitis. Beberapa responden lupa nama dari penyakit periodontal, namun dapat menyebutkan ciri-ciri penyakit periodontal seperti gusi berdarah, pembengkakan gusi, dan keradangan gusi.

Seluruh responden mampu menjawab cara mencegah penyakit periodontal. Beberapa responden hanya menyebutkan satu cara yang paling sering muncul dari jawaban responden adalah memeriksakan gigi ke dokter gigi minimal 6 bulan sekali. Jawaban lain adalah dengan menyikat gigi dua kali sehari setelah sarapan dan sebelum tidur. Sebagian kecil responden masih salah dalam menyebutkan waktu menyikat gigi. Setelah itu, responden diberikan pertanyaan mengenai cara menyikat gigi yang benar. Beberapa kata kunci yang muncul adalah posisi bulu sikat gigi 45 derajat, menyikat secara vertikal dan memutar. Beberapa responden mampu menjelaskan 5 langkah menyikat gigi dengan baik, beberapa hanya mampu menjelaskan hingga posisi bulu sikat dan arah gerakan menyikat gigi.

Pertanyaan terakhir adalah manfaat dari periobrush. Ada beberapa responden yang lupa manfaat dari periobrush dan beberapa mengaku kurang memahami maksud dari manfaat periobrush. Namun, kebanyakan responden mengetahui bahwa periobrush dapat digunakan untuk mengurangi perdarahan (bleeding on probing), menguatkan gusi, dan mencegah terjadinya penyakit periodontal.

\subsection{Webinar Interaktif terhadap Dokter Gigi}

Sebelum dilakukan penyuluhan terhadap dokter gigi puskesmas, dilakukan tes terhadap pengetahuan dokter gigi mengenai kesehatan jaringan periodontal. Hasil pre-test menunjukkan reratap 6,226. Setelah dilakukan penyuluhan dan dilakukan post-test tampak adanya peningkatan pengetahuan dengan rerata skor 8.226. Sehingga, terdapat peningkatan nilai pengetahuan dokter 
gigi terhadap kesehatan jaringan periodontal sebelum dan sesudah penyuluhan.

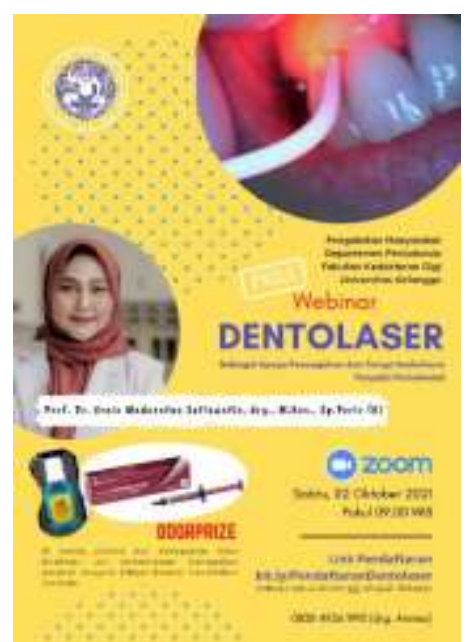

Gambar 3. Poster Kegiatan Interaksi terhadap Dokter Gigi

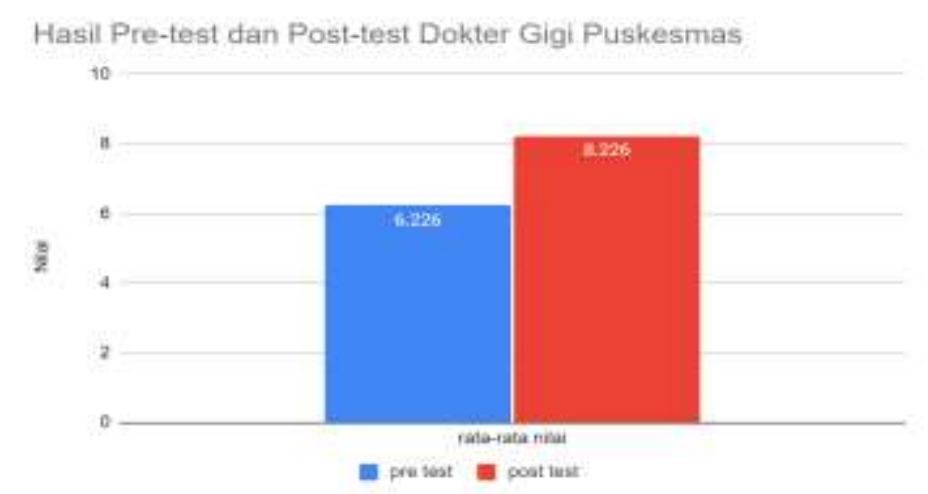

Gambar 4. Hasil Pre dan Post test Dokter Gigi Puskesmas

Dalam webinar ini, tampak dokter gigi mendapatkan pengetahuan baru utamanya terkait penggunaan dentolaser. Alat Dentolaser itu dikembangkan oleh peneliti dan dosen Departemen Fisika, Fakultas Sains dan Teknologi, Prof. Dr. Suryani Dyah Astuti, M.Si. bersama tim peneliti yakni Prof. Dr. Ernie Maduratna Setyawati, drg., M.Kes., SpPerio(K) dan Deni Arifianto, S.Si., M.T. Produk dentolaser yang akan diproduksi massal adalah instrumen medis yang bisa digunakan oleh para dokter gigi sebagai alat terapi gigi dan mulut dengan teknologi laser. Dentolaser dengan panjang gelombang $405 \mathrm{~nm}$ digunakan untuk membunuh bakteri, sedangkan alat yang bisa menghasilkan panjang gelombang $600 \mathrm{~nm}$ difungsikan untuk foto biomodulasi sel. metode terapi dengan fotodinamik memanfaatkan cahaya, fotosensitizer, dan oksigen. Ketiga unsur itu menghasilkan radical oxygen species (ROS) yang akan menyebabkan kematian pada sel yang tidak dikehendaki seperti kanker, mikroba, bakteri, dan virus. Dengan adanya keunggulan yang dimiliki oleh terapi fotodinamik, dentolaser dikembangkan sebagai laser di bidang kesehatan. Sinar yang dihasilkan laser bersifat monokromatik, koheren, dan dayanya lebih tinggi sehingga lama paparan akan lebih pendek. Untuk itulah, ia memanfaatkan laser yang bisa dimanfaatkan untuk mengobati penyakit gigi dan mulut (BRIN, 2017).

\section{KESIMPULAN}

Pengabdian masyarakat ini memiliki potensi untuk menanggulangi permasalahan yang dialami mitra. Dapat disimpulkan bahwa kegiatan pengabdian masyarakat berupa webinar kepada kader dan dokter gigi di Puskesmas Sidoarjo dapat meningkatkan wawasan peserta yang dibuktikan dengan meningkatnya hasil pre-test ke post-test pada peserta. 


\section{DAFTAR PUSTAKA}

BRIN. (2017). Peneliti UNAIR Ciptakan Alat Dentolaser untuk Terapi Gigi dan Mulut. 2017. [Diakses pada 12 Oktober 2021]. Dari : https://www.brin.go.id/peneliti-unair-ciptakanalat-dentolaser-untuk-terapi-gigi-dan-mulut/. Badan Riset Dan Inovasi Nasional.

Hegde, R., \& Awan, K. (2019). Effects of periodontal disease on systemic health. Dis Mon, 65(6), 185-192. https://doi.org/doi: 10.1016/j.disamonth.2018.09.011

Kemenkes RI. (2018). Riset Kesehatan Dasar Tahun 2018. Badan Penelitian Dan Pengembangan Kesehatan Kementerian Kesehatan Republik Indonesia, 198. 


\section{Halaman Ini Dikosongkan}

